\title{
MODEL MANAJEMEN PESERTA DIDIK MADRASAH (STUDI KASUS MADRASAH TSANAWIYAH MODEL PRAYA)
}

\author{
HAROMAIN \\ Program Studi Administrasi Pendidikan Universitas Pendidikan Mandalika \\ haromain@undikma.ac.id
}

\begin{abstract}
ABSTRAK
Artikel ini adalah hasil penelitian yang menggambarkan tentang manajemen peserta didik berbasis madrasah yang difokuskan pada aspek proses penerimaan, pembinaan serta evaluasi program pembinaan peserta didik. Metode penelitian menggunakan pendekatan kualitatif dengan rancangan studi kasus di MTs Negeri Model Praya. Hasil penelitian menunjukkan bahwa proses penerimaan peserta didik baru dilaksanakan dengan sistem terbuka dengan prosedur dan program yang telah disusun sebelumnya. Kegiatan pembinaan peserta didik mencakup aspek akademik dan non akademik. Sedangkan kegiatan evaluasi dilakukan melalui tahapan evaluasi semester dan tahunan. Pemberian reward, publikasi prestasi serta jam tambahan bagi peserta didik adalah tindak lanjut dari hasil proses evaluasi yang telah dilaksanakan sebelumnya.
\end{abstract}

Kata kunci : Manajemen madrasah, penerimaan peserta didik baru

\section{PENDAHULUAN}

Peserta didik menurut ketentuan umum Undang-Undang No. 20 tahun 2003 tentang sistem pendidikan nasional adalah anggota masyarakat yang berusaha mengembangkan potensi diri melalui proses pembelajaran yang tersedia pada jalur, jenjang, dan jenis pendidikan tertentu. Peserta didik adalah sosok manusia sebagai individu/pribadi (manusia seutuhnya). Individu diartikan seseorang tidak tergantung dari orang lain, dalam arti benar-enar seorang pribadi yang menentkan diri sendiri dan tidak dipaksa dari luar, mempunyai sifat sifat dan keinginan sendiri (Ahmadi,2001:39)

Salah satu bentuk lembaga pendidikan keagamaan yang merupakan suatu rangkaian proses pembelajaran yang berciri khas islam adalah madrasah, dimana di dalamnya terdapat keterkaitan antara kelembagaan, tenaga pendidik dan peserta didik beserta unsur-unsur lain yang terkait (Haromain, 2014). Eksistensi madrasah dalam tradisi pendidikan islam yang ada di Indonesia tergolong modern yang kehadirannya dimulai sekitar permulaan abad ke 20.

Kehadiran madrasah sebagai lembaga pendidikan islam di indonesia setidak-tidaknya mempunyai beberapa latar belakang, yaitu: (1) sebagai manifestasi atau realisasi pembaharuan sisitem pendidikan islam; (2) usaha penyempurnaan terhadap sistem pesantren ke arah suatu sistem pendidikan yang lebih memungkinkan lulusannya untk memperoleh kesempatan yang sama dengan sekolah umum, misalnya kesempatan kerja dan problem ijazah; (3) adanya sikap mental pada sementara golongan umat islam, khususnya santri yang terpaku pada budaya barat sebagai sistem pendidikan mereka; sebagai upaya untuk menjembatani antara sistem pendidikan modern dan hasil akulturasi.

Dalam prosesnya, keberadaan madrasah sebagai lembaga pendidikan Islam dikelompokkan menjadi dua jenis yaitu madrasah negeri yang dikelola oleh pemerintah, dalam hal ini Kementerian Agama Republik Indonesia, dan madrasah swasta yang dikelola masyarakat/swasta sesuai dengan jenjangnya masing-masing yaitu Raudlaul Athfal (RA), Madrasah Ibtidaiyah (MI), Madrasah Tsanawiyah (MTs), dan Madrasah Aliyah (MA).

Berdasarkan data awal yang diperoleh peneliti pada saat melakukan observasi di Kabupaten Lombok Tengah, terdapat 12 kecamatan yang masing-masing kecamatan memiliki 1 madrasah tsanawiyah negeri dan madrasah tsanawiyah swasta yang bervariasi antara 6 sampai dengan 15 madrasah swasta di antara 12 madrasah tsanawiyah negeri yang ada di Kabupaten Lombok Tengah, terdapat 1 madrasah tsanawiyah yang menjadi madrasah model yaitu Madrasah Tsanawiyah Negeri Model Praya. 
Keunikan yang dimiliki oleh Madrasah Tsanawiyah Negeri Model Praya antara lain: (1) madrasah ini memiliki kelas unggulan, (2) sistem rekrutmen peserta didik pada kelas unggulan dilakukan melalui jalur undangan kepada calon peserta didik, (3) kurikulum yang diterapkan merupakan perpaduan antara kurikulum Kementerian Pendidikan dan Kebudayaan serta kurikulum Kementerian Agama, (4) antusiasme masyarakat Lombok Tengah untuk menyekolahkan putra-putrinya pada madrasah tsanawiyah ini sangat tinggi terbukti dari jumlah calon peserta didik yang mendaftar pada madraasah tsanawiyah ini terus meningkat, dan (5) lulusan madrasah tsanawiyah ini rata-rata bisa diterima dan menjadi peserta didik berprestasi di sekolah-sekolah unggulan yang ada di Kabupaten Lombok Tengah.

Berdasarkan keunggulan-keunggulan yang terdapat pada madrasah ini, peneliti tertarik untuk melakukan penelitian yang berkaitan dengan manajemen peserta didik pada madrasah tsanawiyah tersebut yang difokuskan pada aspek rekrutmen, pembinaan dan evaluasi peserta didik berbasis madrasah.

\section{METODE PENELITIAN}

Penelitian ini menggunakan pendekatan kualitatif dengan rancangan studi kasus di MTs Negeri Model Praya. Pendekatan penelitian secara kualitatif memiliki prosedur penelitian untuk menghasilkan data deskriptif berupa kata tertulis atau lisan dari orang dan dari prilaku yang diamati melalui prosedur penelitian kualitatif yaitu: (a) penetapan informan kunci yakni Kepala Madrasah, Guru, ketua Komite sekolah dan orang tua/wali murid, (b) melakukan penelusuran data lapangan dengan cara observasi/pengamatan, wawancara, dan studi dokumentasi terkait fokus penelitian, (c) menganalisis data dengan cara mengaudit data, pemberian nomor dan kode data, menganalisis makna data, melakukan pengecekan kembali kebenaran data kepada informan (member check), melakukan konfirmasi data atau pengecekan data melalui sumber informasi terkait lainnya dalam bentuk triangulasi, (d) melakukan penayangan data (display data), (e) penarikan kesimpulan dalam bentuk proporsi temuan penelitian, dan (f) penetapan kesimpulan, rekomendasi hasil penelitian.

\section{HASIL DAN PEMBAHASAN}

\section{Penerimaan Peserta Didik Baru}

Penerimaan peserta didik baru yang merupakan agenda tahunan sebuah lembaga pendidikan harus disusun dan dirancang sedemikian rupa sehingga mampu menjadi langkah awal yang positif bagi perkembangan lembaga pendidikan tersebut dimasa yang akan datang. Dalam hal ini, perumusan terhadap kebijakan-kebijakan yang berkaitan dengan penerimaan peserta didik baru harus dilakukan secara bersama untuk dapat menjaga dukungan dan transparansi dalam proses penerimaan peserta didik baru. Setiap komponen yang ada dimadrasah dilibatkan sesuai dengan hirarki peran dan tanggung jawabnya masing-masing. keterbukaan terhadap setiap proses yang berlangsung menjadi faktor yang sangat menentukan bagi keberlangsungan kepercayaan masyarakat terhadap lembaga pendidikan tersebut.

Madrasah Tsanawiyah Negeri Model Praya yang merupakan lembaga pendidikan negeri dalam perumusan kebijakan-kebijakan yang berkaitan dengan penerimaan peserta didik baru dilakukan dengan melibatkan komite madrasah. Kebijakan-kebijakan operasional berkaitan dengan proses yang berhubungan dengan pertanyaan apa, siapa, kapan, dimana, dan bagaimana melakukan penerimaan peserta didik baru. Perumusan terhadap program dan prosedur yang akan dilaksanakan dalam proses penerimaan peserta didik baru menjadi faktor yang sangat menentukan kelancaran proses yang akan berlangsung.

Kebijakan operasional penerimaan peserta didik baru di madrasah memuat aturan mengenai jumlah peserta didik yang dapat diterima. Penentuan mengenai jumlah peserta didik, juga didasarkan atas kondisi madrasah. Kebijakan operasional penerimaan peserta didik, juga memuat sistem pendaftaran dan seleksi atau penyaringan yang akan diberlakukan untuk peserta didik. Selain itu, keijakan penerimaan peserta didik, juga berisi mengenai waktu pendaftaran, kapan dimulai dan diakhiri. Selanjutnya, kebijakan penerimaan peserta didik harus juga 
memuat tentang personalia yang akan terlibat dalam pendaftaran, seleksi dan penerimaan peserta didik (Imron, 2011).

Penyebaran informasi yang berkaitan dengan penerimaan peserta didik baru menjadi langkah selanjutnya setelah perumusan kebijakan-kebijakan penerimaan peserta didik baru. Dalam hal ini, informasi yang disampaikan kepada masyarakat khususnya orang tua siswa dapat dilakukan melalui beberapa cara, yaitu: pertama, menyebarkan undangan langsung kepada sekolah dasar dan madrasah ibtidaiyah. Hal ini dilakukan untuk dapat menjaring peserta didik berprestasi untuk bisa masuk pada kelas unggulan yang disediakan oleh madrasah. Selain itu, penyebaran undangan langsung ini memuat persyaratan utama yang harus dipenuhi oleh calon peserta didik baru yaitu perolehan rekomendasi dari sekolah mereka untuk dapat masuk di kelas unggulan. Kedua; melalui web madrasah yang didalamnya berisi segala informasi yang berkaitan dengan madrasah.

Informasi yang telah disebarkan oleh madrasah selanjutnya di tindak lanjuti dengan melakukan pembukaan pendaftaran penerimaan peserta didik baru. Untuk calon peserta didik pada kelas unggulan, pembukaan pendaftaran dilakukan lebih awal dari jadwal penerimaan kelas regular. Dalam prosesnya, pembukaan pendaftaran pada kelas unggulan dilakukan sebelum pelaksanaan ujian nasional sekolah dasar. Nilai raport menjadi bahan penilaian bagi pendaftar. Selain itu rekomendasi dari sekolah asal harus dibawa oleh calon siswa untuk dapat masuk di kelas unggulan.

Calon peserta didik yang telah mendaftar selanjutnya dilakukan seleksi administrasi, seleksi akademik dan seleksi kemampuan membaca Al-Qur'an. Seleksi administrasi merupaka seleksi terhadap kelengkapan administrasi calon peserta didik. Bila calon peserta didik tidak dapat memenuhi persyaratan administrasi yang telah ditentukan sebagai syarat masuk, maka secara tidak langsung yang bersangkutan tidak akan dapat mengikuti seleksi selanjutnya yaitu seleksi akademik dan seleksi membaca Al-Qur'an.

Seleksi akademik yang diberikan kepada calon peserta didik ditekankan pada pengetahuan umum yang telah diperoleh pada jenjang pendidikan sebelumnya. Sedangkan seleksi membaca Al-Qur'an merupakan seleksi terakhir yang harus di ikuti oleh calon peserta didik baru. Kemampuan mereka dalam membaca Al-Qur'an secara fasih dan benar menjadi syarat paling utama bagi kelulusan mereka di madrasah. Terlebih lagi pada calon peserta didik yang masuk pada kelas unggulan, syarat paling utama yang harus dipenuhi adalah memiliki hafalan sekurang-kurangnya dua juz.

Langkah terakhir dari rangkaian proses penerimaan peserta didik berbasis sekolah adalah pengumuman hasil seleksi. Pada kasus 1, pengumuman hasil seleksi dilakukan dua tahap yaitu pengumuman hasil seleksi administrasi dan hasil seleksi akademik. Pengumuman hasil seleksi administrasi sebagai rekomendasi bagi calon peserta didik untuk dapat melanjutkan seleksi akademik atau tidak. Sedangkan pada kasus 2, pengumuman hasil seleksi dilakukan pada akhir proses seleksi penerimaan peserta didik baru.

Dalam prosesnya, terdapat beberapa persoalan yang dihadapi madrasah dalam pelaksanan penerimaan peserta didik baru, antara lain: pertama, ketidak singkronan antara nilai raport calon pelamar pada kelas unggulan dengan hasil tes akademik. Hal ini menjadi persoalan tersendiri mengingat kemampuan calon peserta didik pada kelas unggulan harus setingkat diatas peserta didik pada kelas regular. Maka untuk mengatasi persoalan ini, madrasah melakukan pengkajian ulang terhadap tingkat kesulitan soal yang diberikan kepada calon peserta didik baru. Artinya bahwa standar kelulusan diturunkan setingkat dari apa yang sudah di tentukan.

Kedua, dominasi calon peserta didik yang berasal dari lingkungan sekitar madrasah. Tuntutan masyarakat sekitar lingkungan madrasah agar menerima putra-putrinya sebagai peserta didik menjadi persoalan yang hampir setiap tahun dihadapi. Nama besar sebagai madrasah model menjadi magnet tersendiri bagi masyarakat untuk berlomba-lomba memasukkan putra-putrinya terutama yang berasal dari lingkungan sekitar madrasah. Padahal bila di telisik lebih jauh, nama besar sebagai madrasah model seharusnya dapat memberikan 
akses yang besar bagi setiap warga masyarakat dari seluruh wilayah yang ada di Kabupaten Lombok Tengah.

Untuk mengatasi persoalan yang berkaitan dengan dominasi peserta didik yang berasal dari lingkungan sekitar madrasah, penyebaran informasi dan undangan dilakukan lebih awal. Selain itu, optimalisasi peran kelompok kerja madrasah dalam menyebarkan informasi juga menjadi salah satu upaya yang dilakukan untuk mengantisipasi kemungkinan tingginya jumlah pendaftar dari lingkungan sekitar madrasah.

\section{Pembinaan Peserta Didik Baru}

Pembinaan peserta didik di fokuskan pada aspek akademik dan non akademik. Aspek akademik berkaitan dengan pembinaan kemampuan bahasa asing (Inggris dan Arab), pembinaan dalam bidang sains serta pembinaan dalam bidang agama. Sedangkan pada aspek non akademik menekankan pada kemampuan membaca Al-Qur'an serta peningkatan prestasiprestasi non akademik.

Pembinaan aspek akademik yang menekankan pada peningkatan kemampuan sains, kemampuan berbahasa serta pendalaman dalam bidang agama dilakukan melalui beberapa cara antara lain melalui pemberian jam tambahan bagi kelas unggulan yang diberikan pada setiap harinya. Pemberian jam tambahan ini sendiri lebih ditekankan pada mata pelajaran-mata pelajaran utama yang di ujian nasionalkan. Selain itu, pemberlakukan area khusus bahasa asing (language area) dilakukan untuk membiasakan peserta didik berkomunikasi menggunakan bahasa diluar bahasa sehari-hari mereka. Penerapan area khusus bahasa ini berdampak pada peningkatan kemampuan bahasa asing peserta didik yang tentunya juga berdampak pada peningkatan prestasi khususnya dalam bidang bahasa.

Olimpiade-olimpiade siswa juga menjadi salah satu ajang pembinaan peserta didik. Olimpiade-olimpiade yang diadakan baik pada tingkat lokal maupun nasional menjadi penyemangat bagi setiap komponen yang ada di madrasah untuk terus mengasah dan meningkatkan kemampuan yang dimilikinya.

\section{Evaluasi Pembinaan Peserta Didik}

kegiatan evaluasi pembinaan peserta didik pada aspek akademik mengikuti hirarki peran dan tanggung jawab masing-masing pembina mata pelajaran. Evaluasi dilakukan dengan tujuan untuk mengetahui sampai sejauh mana tingkat keberhasilan program pembinaan yang telah dilakukan. Dalam prosesnya, kegiatan evaluasi pembinaan mengikuti alur yang telah ditetapkan. Kegiatan evaluasi akhir semester dan ujian nasional menjadi momentum yang sangat tepat untuk mengetahui tingkat efektifitas pembinaan yang telah dilakukan pada tiap semester dan akhir tahun.

Sedangkan evaluasi pada aspek non akademik dilakukan langsung oleh pembina ekstrakurikuler yang menjadi penanggung jawab kegiatan. Hasil evaluasi ini selanjutnya diserahkan kepada wali kelas untuk dimasukkan pada laporan hasil belajar siswa yang nantinya akan menjadi salah satu bentuk pertanggung jawaban madrasah kepada orang tua peserta didik. Prestasi-prestasi yang diraih peserta didik dalam even-even olimpiade menjadi salah satu acuan penilaian pada evaluasi pembinaan peserta didik dalam bidang non akademik.

Tindak lanjut terhadap hasil evaluasi dilakukan melalui beberapa cara antara lain pemberian reward bagi peserta didik yang berprestasi, pemberian jam tambahan untuk mata pelajaran yang di ujian nasionalkan, pemberian remedial bagi peserta didik yang dianggap belum mampu menuntaskan materinya serta optimalisasi kegiatan-kegiatan ekstrakurikuler madrasah.

Pemberian reward bagi peserta didik yang berprestasi dilakukan salah satunya dengan membebaskan biaya pendidikan peserta didik yang berkisar antara satu hingga dua semester bergantung pada tingkatan prestasi yang diraihnya. Selain itu, publikasi terhadap prestasi yang diraih peserta didik juga menjadi salah satu bentuk penghargaan yang diberikan madrasah yang berdampak pada peningkatan motivasi belajar peserta didik lainnya. 
Pemberian jam tambahan untuk mata pelajaran yang di ujian nasionalkan bertujuan untuk terus mengasah kemampuan yang dimiliki peserta didik khususnya pada mata pelajaran utama. Pemberian jam tambahan ini sendiri didasarkan pada pengalaman tahun-tahun sebelumnya yang diperoleh dari kegiatan ujian nasional. Sedangkan pemberian remedial untuk peserta didik yang dianggap belum mampu menuntaskan materinya dilakukan untuk memperbaiki dan meningkatkan kemampuan yang dimiliki oleh peserta didik.

\section{KESIMPULAN}

Sistem penerimaan peserta didik baru berbasis madrasah berkaitan dengan perumusan kebijakan penerimaan peserta didik baru, pelaksanaan penerimaan peserta didik baru dilakukan dengan sistem terbuka, perumusan prosedur dan program penerimaan peserta didik baru oleh panitia yang telah di bentuk, penyebaran informasi dan undangan penerimaan peserta didik baru melalui brosur, media penyiaran/radio, serta majlis taklim, pembukaan dan pendaftaran penerimaan peserta didik baru, kegiatan seleksi yang meliputi seleksi administrasi, seleksi akademik dan seleksi kemampuan membaca Al-Qur'an serta pengumuman hasil seleksi penerimaan peserta didik baru.

Aspek pembinaan peserta didik berbasis sekolah di fokuskan pada pembinaan aspek akademik dan non akademik. Aspek akademik berkaitan dengan pembinaan kemampuan bahasa asing (Inggris dan Arab), pembinaan dalam bidang sains serta pembinaan dalam bidang agama. Sedangkan pada aspek non akademik, pembinaan peserta didik ditekankan pada kemampuan membaca Al-Qur'an serta peningkatan prestasi-prestasi non akademik.

Evaluasi pembinaan peserta didik berbasis madrasah dilakukan mengikuti hirarki peran masing-masing unit. Pelaksana evaluasi adalah penanggung jawab bidang pembinaan. Evaluasi dalam bidang akademik dilakukan dua tahap yaitu evaluasi semester dan evaluasi tahunan sedangkan evaluasi non akademik dilihat hasil perubahan prilaku peserta didik yang terekam dalam buku kontrol peserta didik. Tindak lanjut hasil evaluasi pembinaan peserta didik dilakukan melalui beberapa cara yaitu: (1) pemberian reward kepada peserta didik yang berprestasi, (2) pemberian jam tambahan pada mata pelajaran yang di ujian nasionalkan, (3) pemberian remedial bagi peserta didik yang dianggap belum mampu memenuhi kriteria ketuntasan minimal (KKM), dan (4) optimalisasi kegiatan ekstrakurikuler madrasah.

\section{DAFTAR PUSTAKA}

Ahmadi. (2001). Manajemen Sekolah. Jakarta. Bumi Aksara.

Arifin, I. (2009). Kepemimpinan Kepala Sekolah dalam Mengimplementasikan Pembelajaran Sentra. Yogyakarta: Aditya Media

Haromain. (2014). Manajemen Pengembangan Sumber Daya Manusia di Pondok Pesantren. Jurnal Pendidikan Humaniora, Jilid 1 Terbitan No. 2 Hal. 136-149.

Imron. (2011). Manajemen Peserta Didik Berbasis Sekolah, Jakarta. Bumi Aksara

Mantja, W. (2009). Modul Perkuliahan Prapasca:Kapita Selekta Manajemen Pendidikan. Program Pasca Sarjana: Universitas Negeri Malang.

Republik Indonesia. (2003). Undang-Undang Sistem Pendidikan Nasional. UU Nomor 20

Tahun 2003 